\title{
Információs technológiák a szociális felsőoktatásban
}

A tanulmány egy olyan kérdőíves vizsgálatról számol be, melynek válaszadói a szociális munkások képzésének tananyagában szereplő informatikai kurzusok oktatói közül kerültek ki. A kutatás a következő kérdésekre koncentrált: milyen a szociális képzésekbe bekerülő hallgatók informatikai felkészültségének értékelése; milyen típusú informatikai tárgyú kurzusok jelennek meg a tantervekben; hogyan illeszkednek az oktatott technológiák a gyakorlati elvárásokhoz; milyen a kurzusok szoftverellátottsága és intézményi infrastrukturális háttere; milyen súlyt helyeznek a képzés helyszínei az online megjelenésre.

Kulcsszavak: szociális felsőoktatás, informatika, szoftverellátottság, infrastruktúra, online megjelenés

\section{Szerzői információ:}

\section{Molnár Dániel}

Szociológus, a Pécsi Tudományegyetem Bölcsészettudományi Kar politikatudományi doktori programjának hallgatója. Három szak ötféle tanulmányi programjában vezet informatikai tárgyú kurzusokat.

E-mail: daniel@btk.pte.hu

Így hivatkozzon erre a cikkre:

Molnár Dániel. „Információs technológiák a szociális felsőoktatásban”.

Információs Társadalom VI, 2. szám (2006): 77-85. 
Molnár Dániel

\section{Információs technológiák \\ a szociális felsôoktatásban}

A szociális felsőoktatás információs és kommunikációs technológiáinak áttekintése eddig nem került a témakörrel foglalkozó vizsgálatok középpontjába. Fontosságát az támaszthatja alá, hogy a képzésekben részt vevố hallgatók jelentôs hányada a késóbbiekben a közigazgatás különböző szintjein fog dolgozni, informatikai felkészültségük pedig kihat majd az e-kormányzati technológiák alkalmazhatóságának mértékére. A témakör jelen áttekintése egy olyan kérdőíves vizsgálatra épül, melynek válaszadói a szociális képzésekben információs technológiákkal foglalkozó kurzusok oktatói közül kerültek ki. A mintába azok a felsốoktatási intézmények kerültek be, melyek a 2006. évi felvételi eljárás során szociális munka vagy szociálpedagógia szakra hirdettek felvételt.*

A felmérés során a következó kérdésekre koncentráltunk: milyen a szociális képzésekbe bekerülő hallgatók informatikai felkészültségének értékelése; milyen típusú informatikai tárgyú kurzusok jelennek meg a képzésekben; hogyan illeszkednek az oktatott technológiák a gyakorlati elvárásokhoz; milyen a szoftverellátottság, illetve az intézményi infrastruktúra; milyen súlyt helyeznek a képzóhelyek az online megjelenésre. Az említett témakörökbe való betekintés reményeink szerint segítheti a szociális képzések informatikai anyagára vonatkozó ajánlások, szabványok kialakítását.

\section{A hallgatók informatikai felkészültségének értékelése}

A Nemzeti alaptanterv (NAT) ${ }^{1}$ jelentős hangsúlyt fektet az informatikaoktatásra, amely a múveltségi területek között 2-10\%-os aránnyal szerepel. Óraszámokra lefordítva ez azt jelenti, hogy minden felsố tagozatos általános iskolás és középiskolás hetente legalább egy órában foglalkozik a témakörrel. A fejlesztési feladatok elméletileg megfelelő mértékben felkészíthetik a tanulókat az információs társadalom aktív polgárának szerepére, valamint megalapozhatják a további, szakirányú informatikai tanulmányokat. A tantárgy súlypontjait az alábbi felsorolás mutatja be:

* Az Országos Felsốoktatási Információs Központ tájékoztatója szerint 20 ilyen intézmény van, ezek közül a következốktôl kaptunk értékelhetô válaszokat: Debreceni Egyetem Egészségügyi Főiskolai Kar, Eötvös Lóránd Tudományegyetem Társadalomtudományi Kar, Eszterházy Károly Fốiskola, Nyugat-Magyarországi Egyetem Benedek Elek Pedagógiai Fôiskolai Kar, Pécsi Tudományegyetem Bölcsészettudományi Kar, PTE Egészségügyi Fốiskolai Kar, Széchenyi István Egyetem, Szegedi Tudományegyetem Egészségügyi Fôiskolai Kar.

${ }^{1}$ A 243/2003. (XII. 17.) sz. kormányrendelet a Nemzeti alaptanterv kiadásáról, bevezetéséról és alkalmazásáról. 


\section{Az informatikai eszközök használata}

2. Informatika: alkalmazói ismeretek

2.1. A gyakorlati életben használt legfontosabb írásos formátumok gépi megvalósítása, igény a mondanivaló lényegét tükröző esztétikus külalak kialakítására 2.2. Adatbázisok, adattáblák alkalmazása, keresés adatbázisokban

3. Infotechnológia (problémamegoldás informatikai eszközökkel és módszerekkel) 3.1. Az adott probléma megoldásához szükséges módszerek és eszközök kiválasztása

3.2. Algoritmizálás, adatmodellezés (a hétköznapi életben és az iskolában előforduló tevékenységek algoritmizálható részleteinek felismerése és különféle formákban történő megfogalmazása)

3.3. Egyszerúbb folyamatok modellezése, a paraméterek módosítása

\section{Infokommunikáció}

5. Médiainformatika

6. Az információs társadalom

7. Könyvtári informatika

A NAT-ból kiindulva tehát a fiatalabb hallgatók esetében megfelelő szintú informatikai, számítástechnikai ismeretekkel számolhatnak a felsőoktatási intézmények. Sajnos a jelenlegi helyzetkép mást mutat. A szociális felsôoktatásba bekerülố nappali tagozatos hallgatók informatikai felkészültségét az érintett oktatók egyike sem értékelte közepesnél jobbra. (Az ötfokozatú skálán 2,62-es átlag született.) A problémát nem az átlagos felkészültség alacsony szintje okozza, hanem az elótanulmányok színvonalában tapasztalható jelentôs szórás. Vannak komoly programozói ismeretekkel, esetenként szakirányú végzettséggel rendelkezô hallgatók, de digitális analfabéták is képesek jó eredménnyel érettségizni és bekerülni a felsőoktatásba. A megfogalmazás túlzónak túnhet, de a digitális analfabetizmus jelenségére illusztris példát nyújtanak azok a fiatalok, akik képtelenek nagybetúket írni a számítógép billentyúzetével.

Egy nagy mintán végzett, reprezentatív felmérés ${ }^{2}$ szerint a magyar középiskolások 40\%-a írt már programot életében. Úgy túnik, ebból a csoportból csak kevesen folytatják tanulmányaikat szociális szakokon, amihez hozzájárulhat az is, hogy ezeknél a képzéseknél a korábbi években nem szerepelt a számítástechnika/informatika a felvételi tárgyak között. Ilyen szempontból a kétszintű képzési rendszer bevezetése kapcsán sem számíthatunk változásra, hiszen a szociális ágba tartozó bachelor szakok egyikénél sem jelenik meg az informatika azon 11 (szociális munka), illetve 12 (szociálpedagógia) tantárgy között, melyek a felvételi pontok számításánál választhatók. A számítógépek világa iránt fokozottabb érdeklődést mutató diákok tehát másfelé orientálódnak, a szociális képzésekbe kerülók többségénél megállapítható, hogy - mint az egyik oktató megfogalmazta - „az informatikai tanegységek nem a kedvenc tanegységeik közé tartoznak".

Az alábbi diagramok a képzésbe belépố nappali és a levelezó tagozaton tanuló hallgatók informatikai felkészültségének értékelését mutatják.

\footnotetext{
${ }^{2}$ Turcsányiné Szabó Márta: Tanítsunk-e programozást? Információs Társadalom, 2003/2.
} 
Nappali tagozat

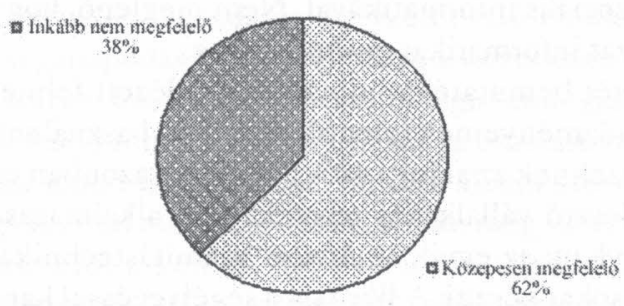

Levelező tagozat

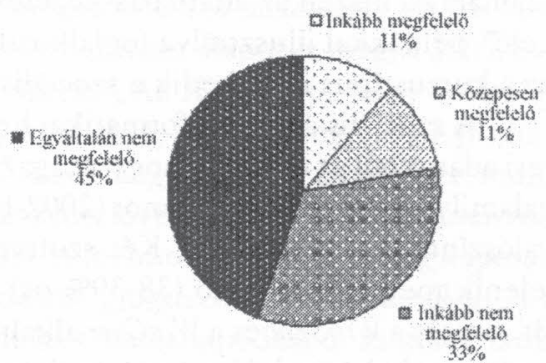

1. ábra

A felkészültség szintjét illetốen pozitív fejlemények is vannak: a válaszadó oktatók a nappali tagozaton jelentôs, a levelezố tagozaton kismértékú javulásról számolnak be:

\begin{tabular}{||l|c|c||}
\hline $\begin{array}{l}\text { Az informatikai felkészültség } \\
\text { színvonala az elmúlt öt évben }\end{array}$ & $\begin{array}{c}\text { Nappali tagozatos hallgatók } \\
\text { esetében }\end{array}$ & $\begin{array}{c}\text { Levelező tagozatos hallgatók } \\
\text { esetében }\end{array}$ \\
\hline Jelentốs mértékben javult & $56 \%$ & $38 \%$ \\
\hline Kismértékben javult & $36 \%$ & $25 \%$ \\
\hline Nem változott & $11 \%$ & $37 \%$ \\
\hline
\end{tabular}

Az eltérố képzési formákban részt vevố hallgatók közötti különbségeket valószínúleg a levelezố tagozat hallgatóinak magasabb átlagos életkorával és az ehhez kapcsolódó másfajta előtanulmányokkal lehet magyarázni.

\section{Kurzusok}

A hallgatók felkészültsége meghatározza az informatikai tárgyú képzések összetételét. Annak érdekében, hogy a képzés elején meglévố tudásszintkülönbségek csökkenjenek, a rendelkezésre álló óraszám jelentôs hányadát kell felzárkóztató jellegú, alapismereteket nyújtó kurzusokra fordítani. Az ilyen típusú kurzusok a leggyakoribbak a szociális képzésekben: „informatika”, „számítástechnika”, ,informatikai alapismeretek" néven találkozhatunk velük. A tematikákban az operációs rendszer múködése, az alapvetô adminisztrációs szoftverek és bizonyos hálózati alkalmazások múködésének áttekintése jelenik meg.

A számítástechnikai alapok meglétét feltételezik azok a kurzusok, amelyek kutatás-módszertani témaköröket állítanak a középpontba. Ilyen tantárgy például a „kvalitatív kutatási módszerek”, az „akciókutatás” vagy a „mérési módszerek komputeres támogatása". A választható kurzusok között megjelennek még az informatika egy-egy részterületére fókuszáló tárgyak is, mint például az „infomédia” vagy a „multimédia-felhasználás".

Sajátosan a szociális ágazat igényeihez igazított kurzust a Vitéz János Római Katolikus Tanítóképzố Fốiskola és a Benedek Elek Pedagógiai Fốiskola indít. A tantárgyak 
középpontjában a társadalomstatisztikai, valamint az adatbázis-létrehozási és -kezelési technikák állnak. Katona György kurzusának vázlata ${ }^{3}$ példaértékú lehet a többi képzés számára is, hiszen az adatbázis-kezelés elméletének és gyakorlatának ismertetésén túl „éló” példákkal illusztrálva foglalkozik a szociális informatikával. Nem meglepô, hogy ez a kurzustípus illeszkedik a szociális ágazat informatikai gyakorlatához.

A szociális ágazat informatikai helyzetét bemutató tanulmányban ${ }^{4}$ idézett felmérési adatokból az derül ki, hogy az ágazat intézményeinek jelentôs részében használnak valamilyen speciális programot (2002-ben ezeknek az aránya $40 \%$ volt, azóta azonban ez valószínúleg növekedett). Két szoftverfejlesztố vállalkozás termékeinek alkalmazása jelenik meg kiemelkedő (38-39\%-os) arányban: az egyik az Abacus Számítástechnikai Bt., amely a WinSzoc és a WinGyer alkalmazásokat készíti. A WinSzoc a segélyezéssel kapcsolatos adatbázisok létrehozásánál, kezelésénél használatos szoftver, amelyet 2002 júniusa óta 350 polgármesteri hivatalban telepítettek. A WinGyer a gyámhivatalok adatnyilvántartási kötelezettségét segíti, mintegy 130 intézményben. A szoftverek ára tartalmazza az oktatás idôszükségletét is, amit a fejlesztô cég 4-6 órában határoz meg. ${ }^{5}$ A másik cég a Közigazgatási Szoftverház, melynek WinIOP (integrált önkormányzati programrendszer) elnevezésú szociális és gyermekvédelmi alkalmazását 2003-ban közel félezer önkormányzat használta. Ennek a szoftvernek az ára is tartalmazza a 4 órányi oktatás díját. ${ }^{6}$ A szoftvereket felhasználó munkatársak oktatására a telepítéskor kerül sor, tehát a késóbb felvett munkatársak felkészítése az adott intézményt terheli. A folyamatot lerövidítendő, célszerü lenne az ilyesfajta szoftverek használatát már az egyetemi, illetve fóiskolai képzés során megismertetni a hallgatókkal.

A informatikai tárgyú kurzusokhoz rendelkezésre álló óraszámot az összes válaszadó kevesellte. „A tantárgy keretében 1 félévben heti 2 óra gyakorlati oktatás folyik (összesen 30 óra). Az ekkora óraszámban megtanítható tananyag nem teszi lehetơvé a gyakran gyengén elóképzett hallgatók felkészítését a színvonalas szakmai munka elvégzésére" - írta egyikük.

\section{Szoftverellátottság}

A hazai felsôoktatás szereplôi számára a magyar állam térítésmentesen biztosít bizonyos Microsoft szoftvereket. Az alkalmazás technológiai hátterét a korábbi Campus szerződésból kinôtt Tisztaszoftver Program biztosítja. A 2005. április elsején közzétett, 2008. február 28-ig érvényben lévô szerződés rendkívül hasznos a szociális ágazat informatikai fejlesztése szempontjából is, hiszen a különféle Windows operációs rendszereken kívül az alapvetố adminisztrációs alkalmazásokat tartalmazó Office szoftvercsomag rendelkezésre bocsátása is a szerződés részét képezi.

\footnotetext{
${ }^{3}$ Informatika a szociális munkában címư kurzus vázlata. 2005.

http://www.bepf.hu/Oktatasi_segedletek/oktatasi_segedletek.html

${ }^{4}$ Eckert Bálint: A szociális ágazat informatikai helyzete. 2005.

http://www.icsszem.hu/download.php?ctag=download\&docID=813\&accessible =0

${ }^{5}$ Abacus Számítástechnikai Bt. - Céginformáció. http://www.abacus-net.hu/ceginfo.htm

${ }^{6}$ Önkormányzati Tájékoztató. XIII. évfolyam, 2. szám, 2003. február.
} 
A program pozitív hozadékai mellett meg kell említeni néhány problematikus pontot is. A Campus szerzôdést számos fórumon kritizálták azon az alapon, hogy az állami forrásokat a Microsoft piacvezető pozíciójának megerôsítésére használják fel. Noha a szoftveróriás gazdasági helyzetét valószínúleg nem ez az üzlet alapozza meg, a 2005. évi megállapodás már tartalmazza a következő célkitûzést: „Az IHM célja, hogy a Tisztaszoftver Program (TP) technológiasemleges legyen, illetve, hogy elősegítse a nyílt forráskódú rendszerek terjedését az oktatásban is." " A cél megvalósítása érdekében munkacsoport is alakult az illetékes állami szervek részvételével, az örömteli fejlemények gyakorlati megvalósítása azonban még várat magára. A technológiasemlegesség kapcsán felmerül a kérdés, hogy ha a hivatalos közlés szerint „jogtisztán használhatók [...] a Microsoft Office termékek", akkor miért maradt ki a megállapodásból az alkalmazás Mac operációs rendszert futtató gépekre írt változata. A nyílt forráskódú Linux esetében annak a Sulinet Expressz programba, illetve a központosított közbeszerzés intézményi köre számára szállítható termékek körébe való bevonásával egyértelmú előrelépés volt tapasztalható. Egy közbeszerzési eljárás során jóval bonyolultabb. A szoftverhez jutás legegyszerúbb módja azonban a megfelelố sávszélességú szerverról való letöltés, amire a TP esetében lehetôség van. A közelmúltban több külföldi és hazai kezdeményezésról lehetett hallani, amelyek a Linux operációs rendszernek a közigazgatásban történő bevezetésére irányultak. A példák a késóbbiekben megalapozhatnák ezen alternatív operációs rendszer oktatásának a szükségességét is a szociális képzésekben, bár erre a válaszadó oktatók szerint jelenleg még nincs szükség.

Amire szükség van, az a Windows, a Word és az Excel. Ezeket az összes válaszadó intézményben használják. Több helyen említik az oktatott szoftverek körében ezek mellett a PowerPointot (56\%) és az SPSS-t (44\%). Az utóbbi az informatikai tárgyú kurzusokon leggyakrabban elóforduló olyan szoftver, amihez az intézmények nem a Tisztaszoftver Program keretében jutnak hozzá. Alkalmazását a HUNINETEgyesület és a magyarországi forgalmazó közötti megállapodás teszi lehetővé, melynek keretében a piaci árnál jóval alacsonyabb licencdíjat befizetoo felsôoktatási intézmények dolgozói és hallgatói korlátlan felhasználási jogot kapnak. Az oktatásban gyakorta megjelenố szoftverek felsorolása az MS Office részét képezó PowerPoint és Access programokkal folytatható. Az említetteken kívül a válaszokban megjelenő további szoftverek (Adobe Acrobat, ATLAS.ti, Audacity, Paint Shop Pro) oktatásával csak egy-egy intézményben találkozunk.

A jelenleg nem oktatott, de a képzésbe bevonni szándékozott szoftverek között a PowerPoint áll az elsố helyen - értelemszerúen azokban az intézményekben, ahol jelenleg nem képezi a tananyag részét. Ez kutatásunk egyik meglepő eredménye, hiszen az Office csomag talán legkönnyebben áttekinthetố és oktatható alkalmazásáról van szó. Van olyan oktató is, aki az Adobe Photoshop és az immáron ugyanehhez a céghez tartozó Flash alkalmazásának oktatásával színesítené a képzést. Nem nehéz felfedezni ebben az elgondolásban a honlapkészítés oktatásának igényét. A válaszadók fele ezt elsősorban a HTML-nyelv alkalmazásába való bevezetéssel szeretné megvalósítani. A jelölônyelv alapjainak elsajátítása nem igényel költséges szoftverberuházást, viszont hatása

\footnotetext{
${ }^{7} \mathrm{Az}$ Informatikai és Hírközlési Minisztérium közleménye a Tisztaszoftver Programról. http://www.ihm.gov.hu/sajtoszoba/kozlemenyek/ihm_microsoft_megallapodas.html
} 
emelheti a kiadott diplomák értékét, hiszen egyre több szociális intézmény jelenik meg saját honlappal a világhálón, jelentôs részük azonban nem rendelkezik megfeleló anyagi forrásokkal ahhoz, hogy erre a célra külön informatikust foglalkoztasson.

\section{Infrastruktúra}

Az informatikai infrastruktúra legmeghatározóbb indikátora a hallgatók számának és a rendelkezésükre bocsátott számítógépek számának az aránya. Az arányszámot firtató kérésre kevés intézményból kaptunk értékelhetố választ, ezért az összesítést a Országos Felsőoktatási Információs Központ honlapján található adatok alapján készítettük el:

\begin{tabular}{|l|c|}
\hline Egy számítógépre jutó hallgatók száma & A kategóriába tartozó intézmények száma \\
\hline 15 vagy kevesebb & 7 \\
\hline $15-29$ & 7 \\
\hline 30 vagy több & 4 \\
\hline
\end{tabular}

Az átlagérték 25 fő; a szélsőértékeket a Károli Gáspár Református Egyetem Tanítóképző Főiskolai Karán (3 fó), illetve a Pécsi Tudományegyetem Bölcsészettudományi Karán találjuk ( 80 fó). Az adatok önmagukban persze nem árulkodnak a géphez jutás esélyéról, mivel arra egyéb tényezók is kihatnak. Meghatározó például a különbözố tagozatokon tanulók aránya, a kollégiumokban található gépek aránya és a hozzáférhetố számítógépek állaga. Témánk szempontjából fontos az is, hogy az adatok a képzéseket folytató karokra és fóiskolákra vonatkoznak, az egyes tanszékekhez tartozó arányok pedig ettól eltérốek lehetnek. (Pécsett például külön gépterem áll a szociális munkás, szociálpolitikus és szociális munkás szakos hallgatók rendelkezésére.)

Az előzőnél relevánsabb adat, hogy a számítástechnikához kapcsolódó kurzusokon minden hallgató külön számítógépen dolgozhat-e. Átlagosan három hallgató jut két számítógépre.

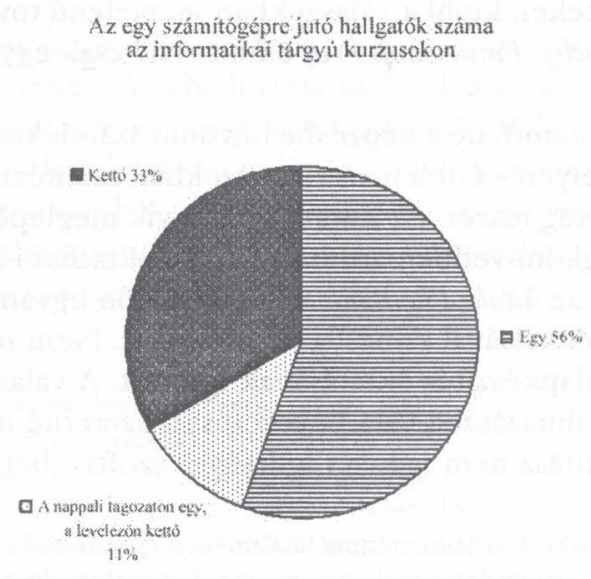

2. ábra 
Noha többségben vannak azok az intézmények, ahol a résztvevók külön munkaeszközt használhatnak, számos képzési helyen ez az optimális állapot nem valósul meg. A manapság széles körben használatos programok pontos múködését, felépítését megismerni az átlagfelhasználó számára szinte lehetetlen. Ami használhatóvá teszi óket, az a hasonló, sok esetben azonos kezelófelület. Ennek logikáját legkönnyebben a gyakorlati alkalmazás során lehet elsajátítani. Az iskolának lehetőséget kell biztosítani erre. Bizonyos feladattípusok esetén (pl. kérdôíves vizsgálatok adatbázisának elkészítése során) a párban végzett munkának hasznos vonásai is lehetnek, az esetek többségében viszont csoportbontással sokkal jobb eredményeket lehet elérni.

A válaszadó oktatók intézményük informatikai infrastruktúráját azonos arányban tartották jónak, közepesnek, illetve rossznak. Az értékelés egyébként nem mutatott kapcsolatot a rendelkezésre álló számítógépek számával.

\section{Online megjelenés}

A szociális képzéseket folytató intézményeknek az információs technológiákhoz fúződő viszonyát látványosan szemlélteti a hálózati megjelenéshez való viszonyuk. Az e tekintetben élenjáró iskoláknak legalább hetente frissített honlapja van, amely egyszerre szolgálja a külsố tájékoztatást, valamint - tantárgyi segédanyagokkal, máshol nem hozzáférhetố tanulmányokkal - az oktatást. Hasonló ismérv az oktatók és a hallgatók elektronikus levelezésének rendszeressége. ${ }^{8} \mathrm{Az}$ online kommunikáció elterjedtségének mértékére vonatkozóan csak becslést tudunk adni: ez a forma valószínúleg gyakoribb azokban az intézményekben, amelyek közzéteszik munkatársaik e-mail címeit. A szúkös költségvetések nyilvánvalóan megnehezítik egy-egy megfeleló tanszéki vagy kari honlap kialakítását és fenntartását, de az esetek egy részében inkább azt lehet feltételezni, hogy az online megjelenés szükségességének mérsékelt fontosságot tulajdonítanak.

A táblázat a szociális képzóhelyek 2006 januárjában elérhető hálózati megjelenésének elemzése alapján készült. Az informativitás megítélésénél az értékelés teljesen objektív módon történt, a következố adatok meglétének ellenốrzésével: elérhetôség, tantervek, online tananyagok, oktatói életrajzok, aktualitások. A használhatóságra vonatkozóan a következő szempontok szerint történt az értékelés: a szakhoz kapcsolódó információk elérhetôsége, honlaptervezés-felépítés. Fontos megemlíteni, hogy több intézményben éppen folyamatban volt a releváns információk feltöltése, és volt olyan tanszék, ahol a közeljövóben esedékes honlapcseréról számoltak be.

\begin{tabular}{|l|l|c|c|}
\hline \multicolumn{1}{|c|}{ Intézmény } & \multicolumn{1}{|c|}{ A honlap típusa } & Informativitás & $\begin{array}{c}\text { Használ- } \\
\text { hatóság }\end{array}$ \\
\hline $\begin{array}{l}\text { AVKF Pszichológia és Szociálpedagógia } \\
\text { Tanszék }\end{array}$ & fóiskolai honlap & 4 & 4 \\
\hline $\begin{array}{l}\text { DE BTK Politikatudományi és Szocio- } \\
\text { lógiai Intézet, Szociológia Tanszék }\end{array}$ & $\begin{array}{l}\text { kari honlap, integrált intézeti és } \\
\text { a hallgatók által gondozott „sza- } \\
\text { kos" honlap }\end{array}$ & 4 & 3 \\
\hline DE EFK & kari honlap & 3 & 4 \\
\hline
\end{tabular}

${ }^{8}$ Kárpáti Andrea: A tudásalapú társadalom pedagógiája és a számítógéppel segített tanulás. Információs Társadalom, 2003/2. 


\begin{tabular}{|c|c|c|c|}
\hline Intézmény & A honlap típusa & Informativitás & $\begin{array}{l}\text { Használ- } \\
\text { hatóság }\end{array}$ \\
\hline $\begin{array}{l}\text { ELTE TáTK Szociális Munka és Szo- } \\
\text { ciálpolitika tanszék }\end{array}$ & önálló tanszéki honlap & 5 & 5 \\
\hline $\begin{array}{l}\text { EKF Alkalmazott Pszichológia és Szoci- } \\
\text { ológia Tanszék }\end{array}$ & kari honlap & 2 & 4 \\
\hline $\begin{array}{l}\text { KJF Európai Közpolitika és Szociális } \\
\text { Szolgáltatásmenedzsment Tanszék }\end{array}$ & $\begin{array}{l}\text { tanszéki információs blokk a fõ̃- } \\
\text { iskola honlapján }\end{array}$ & 3 & 5 \\
\hline KRE TFK Diakóniai Intézet & önálló intézeti honlap & 5 & 4 \\
\hline NyME ATFK & tanszéki blokk a kari honlapon & 2 & 3 \\
\hline $\begin{array}{l}\text { NyME BEPF } \\
\text { Szociálpedagógia Tanszék }\end{array}$ & fốiskolai honlap & 3 & 2 \\
\hline $\begin{array}{l}\text { PTE BTK Szociális Munka és Szociál- } \\
\text { politika Tanszék }\end{array}$ & önálló tanszéki honlap & 4 & 5 \\
\hline $\begin{array}{l}\text { PTE EFK Szociális Munkás Képzố In- } \\
\text { tézet }\end{array}$ & kari honlap & 2 & 2 \\
\hline riOPTE IGYFK Szociálpolitikai Intézet & kari honlap & 2 & 2 \\
\hline $\begin{array}{l}\text { SZE } \\
\text { Egészségügyi és Szociális Intézet } \\
\text { Szociális Munka Tanszék }\end{array}$ & önálló tanszéki honlap & 4 & 5 \\
\hline SZIE JFK Szociálpedagógiai Tanszék & önálló tanszéki honlap & 4 & 5 \\
\hline $\begin{array}{l}\text { SZTE EFK } \\
\text { Szociális Munka és Szociálpolitika Tan- } \\
\text { szék }\end{array}$ & önálló tanszéki honlap & 3 & 4 \\
\hline $\begin{array}{l}\text { TSF } \\
\text { Egészségügyi Intézet Szociális Munka } \\
\text { Tanszék }\end{array}$ & intézeti honlap & 1 & 1 \\
\hline VHF & fôiskolai honlap & 2 & 4 \\
\hline $\begin{array}{l}\text { VJRKTF } \\
\text { Szociális Képzési és Neveléstudományi } \\
\text { Tanszék }\end{array}$ & fốiskolai honlap & 2 & 3 \\
\hline Wesley János Lelkészképzố Fôiskola & fốiskolai honlap & 2 & 2 \\
\hline
\end{tabular}

A szociális képzésekhez kapcsolódó honlapok csoportjára elsôsorban az eklektikusság jellemzố. A külcsín tekintetében ez pozitívumként, az ágazat sokszínúségére való utalásként is értelmezhetô, a tartalmak eltérései azonban megnehezítik az egyes intézmények közötti eltérések és a kapcsolódási pontok meghatározását.

\section{Javaslatok}

A szociális képzésekben jelenleg különbözố tantervek által meghatározott módon, eltéró óraszámban, egyedi tematikák alapján zajlik a hallgatók oktatása az informatika tárgykörében. Az eltérések eredményeként a majdani munkaadók körében is elóállhat a most csak a képzési helyeken érzékelt helyzet, miszerint adott végzettséghez (érettségi, illetve szociális diploma) nem lehet megfelelő́ tudásszintet társítani. Az erre adott válaszlehetốség a megfelelő szakirányú oklevél vagy bizonyítvány igénylése az érintettektôl. Ezt a helyzetet elkerülendô, célszerú lenne a tapasztalatok cseréjén alapuló egyeztetések nyomán kialakuló, egymáshoz közelítő oktatási stratégiát kialakítani.

A vizsgálatban részt vevô oktatók között nem volt olyan, aki a képzés végén megfelelőnekítélte volna a hallgatók informatikai képzettségét. Az alábbi diagramok a képzésból kilépố hallgatók tudásszintjének értékelését mutatják: 
Nappali tagozat

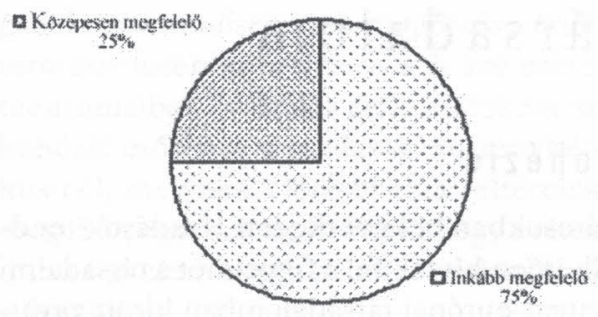

Levelezö tagozat

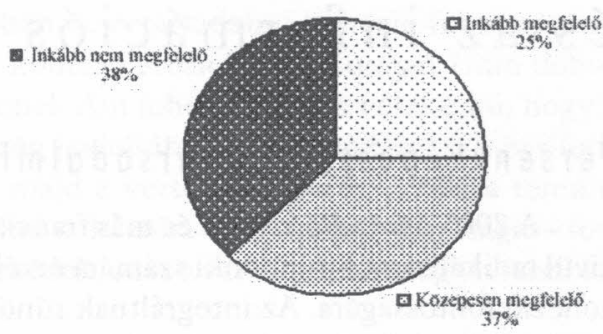

3. ábra

A leírt helyzetet elóidézô okok között számos tényezốre lehet utalni, s ezek közül ki kell emelni a képzésekbe bekerüló hallgatók egy részének alacsony tudásszintjét, a rendelkezésre álló alacsony óraszámot, valamint az infrastrukturális problémákat. A szükséges változtatások egy része meghaladja az érintett képzôhelyek lehetôségeit, de az elsố lépést ezen a szinten kell megtenni, annak tudatosításával, hogy az információs technológiák a szociális ágazat szerves részét képezik. 